UNIVERSIDAD AUTÓNOMA METROPOLITANA

DIVISIÓN DE CIENCIAS SOCIALES Y HUMANIDADES

DEPARTAMENTO DE HUMANIDADES

ESPECIALIZACIÓN EN LITERATURA MEXICANA DEL

SIGLO XX

\title{
SEDUCCIÓN, TRANSGRESIÓN Y EROTISMO EN EL LIBRO DE RUTH DE GILBERTO OWEN
}

TESINA PARA OBTENER EL DIPLOMA DE LA ESPECIALIZACIÓN EN LITERATURA MEXICANA DEL SIGLO XX

PRESENTA: LIC. ÁMBAR HERRERA PADILLA

ASESOR: MTRO. SANDFORD CRAIG COHEN HOROWITZ

CIUDAD DE MÉXICO, NOVIEMBRE 2020

Esta tesina recibió financiamiento del Programa Nacional de Posgrados de Calidad del CONACYT 


\section{ÍNDICE}

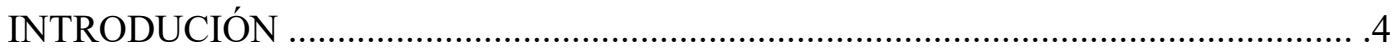

1.- DEL MITO BÍBLICO AL POEMA: LIBRO DE RUTH DE GILBERTO OWEN .... 9

1.1 Un amor entre lo mítico y lo moderno........................................................ 9

1.2 La exégesis del libro bíblico ....................................................................... 11

1.3 Elementos míticos del poema ................................................................... 13

2. LA MÁSCARA Y LA REPRESENTACIÓN EN EL POEMA................................. 17

2.1 Los usos de la máscara ......................................................................... 17

2.2 La revelación de los amantes ................................................................ 22

$2.3 \mathrm{El}$ amante vencido ante la amada............................................................ 25

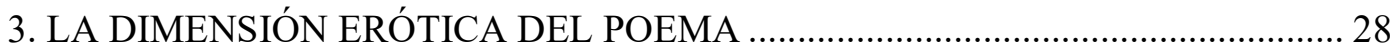

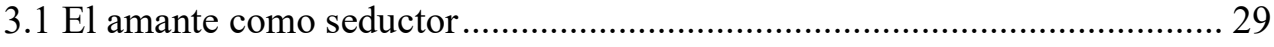

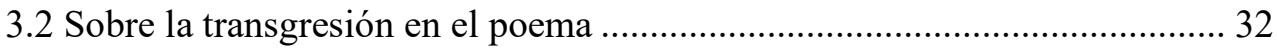

3.3 El encuentro entre Eros y Tánatos en la experiencia erótica ........................ 35

3.4 Poesía y erotismo como continuidad ......................................................... 38

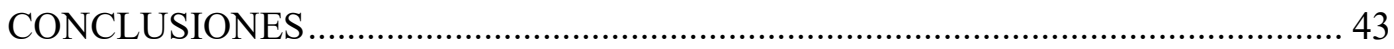

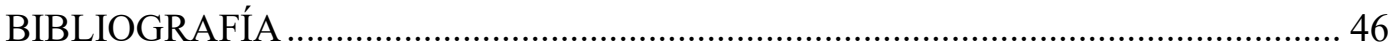




\section{IN MEMORIAM}

\section{Sandro Cohen (1953-2020)}

Soy este cansancio, esta maldición, estas hojas donde estamos vivos, estas palabras que son eternidad, estos seres que son humanos, estas estrellas contra la noche, estos trazos a nuestra imagen, estas ganas de vivir contra toda muerte, este grito de ser... S.C.

Con estas palabras rindo homenaje a la memoria del Mtro. Sandro Cohen que lamentablemente falleció el día 05 de noviembre del 2020 a causa del Covid-19. Sandro Cohen dedicó su vida a la literatura y fue un apasionado de la música, el ciclismo, la docencia y, por supuesto, la poesía. Yo que tuve la suerte de contar con su asesoría para mi proyecto final puedo decir que siempre fue un maestro dedicado que legó a sus alumnos valiosas enseñanzas, anécdotas memorables y su entrañable visión sobre la poesía. En lo personal, pienso que la mejor manera de recordarlo es a través de la lectura de su obra, pues el tesoro de su poesía sigue con nosotros, su lira no ha enmudecido y creo firmemente que siempre encontrará una voz en la cual resonar.

Descase en paz, maestro. 


\section{AGRADECIMIENTOS}

Agradezco a mi familia porque con su apoyo y cariño me impulsaron a continuar con mis estudios. Mucha gracias al Mtro. Sandro Cohen, cuya guía fue fundamental para el desarrollo de esta investigación, así como al Dr. Antonio Marquet y al Dr. Gabriel Ramos que con su atenta lectura y observaciones terminaron por encaminar este proyecto hacia su desenlace exitoso.

Expreso también mi agradecimiento a mi alma máter, la Universidad Autónoma Metropolitana, en donde se ha formado mi espíritu académico, y que este año me ayudó a fortalecer mi trayectoria profesional al aceptarme en la Especialización en Literatura Mexicana del Siglo XX de la UAM- Azcapotzalco. En este mismo sentir, doy gracias a los profesores de Especialización por su dedicación, enseñanza y, sobre todo, por conservar su pasión por la literatura intacta aún en tiempos de crisis.

Finalmente, agradezco al CONACYT por brindar el apoyo económico para el desarrollo y culminación de esta investigación. 


\title{
INTRODUCIÓN
}

\author{
Todos los días 4 son domingos \\ porque los Owen nacen ese día, \\ cuando Él, pues descansa, no vigila \\ $y$ huyen de sed en sed por su delirio. \\ $Y$, además, que ha de ser martes el 13 \\ en que sabrán mi vida por mi muerte. ${ }^{1}$ \\ Gilberto Owen
}

Gilberto Owen escribió alguna vez "sabrán mi vida por mi muerte” y esto resultó ser una predicción pues, efectivamente, tras su fallecimiento su nombre alcanzó mayor fama, gracias a que la crítica emprendió el oportuno rescate de su legado. Hoy en día, la obra de Owen suscita interés sin duda por su riqueza literaria, pero también por sus tintes autobiográficos a través de los cuales se descubre la figura emblemática del más errante de los Contemporáneos. En la obra de Owen coexisten vida y escritura como una unidad singular en donde una da sentido a la otra. La publicación de su correspondencia íntima bajo el nombre de Cartas a Clementina Otero (1988) es un ejemplo claro de cómo la vida del poeta inyecta su escritura. En las lecturas más detalladas de estas cartas se ha podido encontrar algo más que el sentimiento amoroso de un veinteañero, y se han descubierto en sus líneas algunas de las ideas poéticas más importantes de Owen.

El poeta originario del Rosario Sinaloa fue una figura importante de los Contemporáneos, que en el año de 1928 acapararon la escena literaria en México. Los compañeros de Owen en este grupo fueron Carlos Pellicer, Enrique González Rojo, Bernardo Ortiz de Montellano, José Gorostiza, Jaime Torres Bodet, Xavier Villaurrutia, Salvador Novo, Celestino Gorostiza, Rubén Salazar Mallén y Jorge Cuesta; para este último, la conformación de los Contemporáneos se debió más a una feliz "coincidencia del destino", dado que los integrantes tenían intereses tan diversos entre sí que era difícil

\footnotetext{
${ }^{1}$ Estos versos pertenecen al poema "Sindbad el varado" (Día cuatro, Almanaque).
} 
concebirlos como una unidad. No obstante, todos ellos compartían, además de su amistad, una actitud crítica que sería su principal característica como grupo. Al respecto, Guillermo Sheridan reflexiona ampliamente sobre las peculiaridades y la formación del famoso Grupo Sin Grupo:

Los Contemporáneos es un lugar imaginario en el que coincidieron diversos discursos y maneras de ejercer el quehacer literario y cultural entre los años de 1920 y 1932 y alrededor de un cierto número de empresas como revistas, grupos de teatro y sociedades de conferencias. Son una cinta de Moebio, una intencionalidad en constante formación y en constante crisis. Existen más como una azarosa concatenación de voluntades críticas que como un destino literario programático. Se trata, en todo caso, más de una voluntad que de una idea y más de un presupuesto de trabajo que de una voluntad. ${ }^{2}$

Tal como señala Sheridan, pese a sus diferencias, los Contemporáneos lograron posicionarse como las voces críticas de su tiempo, esto gracias a su incansable trabajo crítico y creativo en prácticamente todos los ámbitos culturales del país. Estos jóvenes aspiraron a lo universal y buscaron liberarse de las limitaciones que les imponía el medio cultural de su época, impregnado por la demagogia nacionalista del México posrevolucionario. Este fue el mismo sentir de Owen que a pesar de vivir gran parte de su vida en el extranjero, debido a su trabajo como diplomático, no dejó de participar activamente del espíritu de sus compañeros de grupo, aunque siempre con un perfil más discreto, cuando no desconocido. Owen se dedicó principalmente a la poesía, pero también escribió en prosa novelas como La llama fría (1925), Novela como nube (1928), y otros relatos como Examen de pausas (1928), que hoy están recopilados en sus Obras por Josefina Procopio, Miguel Capistrán, Luis Mario Schneider e Inés Arredondo. Además, Owen ejerció como traductor, periodista y crítico en diversas revistas, pero principalmente en las pertenecientes a su grupo: Ulises (1927-28), Contemporáneos (1928-31) y El Hijo Pródigo (1943-46). Fue también cofundador del Teatro de Ulises

\footnotetext{
${ }^{2}$ Guillermo Sheridan, Los Contemporáneos ayer, México, FCE, 1985, p. 11.
} 
(1926-29) en donde llegó a actuar junto a Clementina Otero, uno de sus grandes amores.

No obstante, a pesar de sus múltiples facetas como intelectual, Owen fue, ante todo, un poeta.

Cuando se habla de la poesía del rosarino a menudo se resalta su hermetismo y la dificultad que impone para su interpretación. El mismo Owen llegó a señalar esta característica al afirmar: "Siempre he sabido leer- y escribir- entre líneas. Son muy pocas las ocasiones en que la pasión me arrastra a lo literal". ${ }^{3}$ Ante esto, es preciso encontrar las coordenadas del mundo poético de Owen para entender su poesía, éstas son las que revelan el significado detrás de cada verso y, más aún, revelan el rostro del poeta detrás de las máscaras del mito. Pero más allá de la complejidad y pulcritud de su composición poética, la poesía de Owen seduce por su entrega ya que es en esencia una poesía muy humana, quizás la más humana que se pueda encontrar dentro de la producción de los Contemporáneos; esto en tanto que Owen privilegia, en cierto modo, la iluminación por la carne, antes que la iluminación por la vía del pensamiento. No tan paradójicamente, aunque lo parezca, Owen se autonombró la conciencia teológica de su grupo, pues afirma que fue él quien les recordó su mortalidad y la inexorable marcha del tiempo:

[...] una tarde le expliqué a Xavier que era mortal. Él no lo creía. No existe, le dije, hablando de unos poemas, lo intemporal. Todo lo que vive está condenado al tiempo. Lo que está puede ser eterno, pero entonces se llama Caos, y no es, no vive. Dios no está, existe. Llegó después del Caos, y morirá cuando el Caos vuelva a estar en todas partes. Dios es mortal y lo son los ángeles, y lo son los Xavieres Villaurrutias y los Elías Nandinos. Aunque ellos no lo crean, y uno en el cielo y el otro bajo el cielo de México me juzguen pedante e ingrato. Porque yo soy su conciencia teológica. ${ }^{4}$

Estas palabras revelan que Owen tenía una amplia comprensión de su condición efímera como hombre y una tendencia hacia el cumplimiento de un designio destructor,

\footnotetext{
${ }^{3}$ Gilberto Owen, Obras, México, FCE, 1996, p. 281.

${ }^{4}$ Ibid., p. 290.
} 
al cual se alude constantemente en su poesía y que en su vida muchos han relacionado con su adicción al alcohol, ${ }^{5}$ tema que también es recurrente en sus poemas.

En el prólogo a sus Obras, Alí Chumacero señala que Owen era un hombre apegado a la tierra y con plena conciencia de que su obra "era el reflejo y la dócil respuesta a la contemplación de lo que no perdura, a la inevitable presencia de lo que muere frente a nuestros ojos, y entraba en la poesía dejando a la puerta toda esperanza". ${ }^{6}$ No obstante, Owen fue capaz de afrontar su inminente destrucción a través de la poesía. De esta intención se desprende una de sus tantas coordenadas, esto es la alusión al mito o, mejor dicho, su afición a la desmitificación de los héroes clásicos como Ulises, Sindbad o Perseo, a quienes devuelve su naturaleza humana, a fin de mostrar la crisis existencial que atraviesa el hombre moderno.

El texto que el lector tiene ahora en sus manos se centra en el estudio del poema de largo aliento titulado Libro de Ruth (1946), en donde Owen emprende exitosamente la desmitificación del libro homónimo de la Biblia. Este relato, usualmente estudiado como una historia de salvación por sus atributos mesiánicos, es tocado por la poesía y se convierte en un poema de amor que exalta la virtud de la carne y de la experiencia erótica en la vida del ser humano. Para entrar en contexto, un primer capítulo está dedicado al análisis del texto bíblico y de los elementos míticos que Owen retoma para su recreación. Aquí se verá la importancia de este romance para el poeta y los elementos que elige mitificar, así como la función que cumplen las máscaras de los personajes principales en la expresión poética.

\footnotetext{
${ }^{5}$ Hacia el final de su vida Owen tenía cirrosis hepática y estaba ciego debido a su adicción al alcohol. Falleció a los 48 años el 9 de marzo de 1952. El alcoholismo como tema en su poesía se ve representado sobre todo en "Sindbad el varado"; por ejemplo, en los versos: "Alcohol, ancla segura y abolición de la aventura", que fueron recitados por el poeta en plena borrachera y bajo un torrencial aguacero, según cuenta Álvaro Bejarano en "Abolición de la Aventura. Gilberto Owen en Colombia", Biblioteca de México, núm.14, México, CONACULTA, 1993, p. 40.

${ }^{6}$ Alí Chumacero, "Prologo" en Owen, op.cit., p. 9.
} 
El siguiente capítulo comenta las cualidades transgresoras del poema oweniano. La inserción del epígrafe bíblico al inicio del poema, por ejemplo, ya indica la reelaboración del romance mítico como un ritual erótico, éste comprende desde la espera ansiosa de Booz en la medianoche, hasta la llegada de la Ruth la moabita, que se recuesta a sus pies pidiendo ser redimida. En el poema el personaje de Booz funciona como máscara del amante oweniano, un héroe moderno cuya hazaña es su derrota ante la experiencia del amor; sin embargo, conforme avanza el poema, el amante se desvela como seductor, porque sabe que en el terreno de la seducción abrazar la derrota es el camino para salir airoso.

Finalmente, el tercer capítulo se centra en la exposición de dimensión de Eros en el poema a través de la lectura de los elementos eróticos. Lo anterior se realiza bajo las nociones de continuidad y discontinuidad postuladas por George Bataille, a fin de explicar el carácter de la experiencia erótica como un medio para la prolongación y la trascendencia del ser, pues en ésta se abandona la individualidad para ser uno con el cuerpo de un otro. Asimismo, el momento del clímax erótico es la desintegración de las barreras que separan al hombre de sus prójimos, en ese momento de apertura, tan cercano a la muerte, el cuerpo deja de ser una unidad aislada y se vuelve parte del todo. De este tipo de experiencias emana la poesía que, en sí misma, posee la capacidad de trascender el lenguaje al regresar a la palabra su cualidad de representar no uno, sino múltiples significados del mundo. 


\section{DEL MITO BÍBLICO AL POEMA: LIBRO DE RUTH DE GILBERTO OWEN}

\section{Un amor entre lo mítico y lo moderno}

Hacia 1946 Gilberto Owen publica por vez primera su poema Libro de Ruth, un manuscrito de 16 páginas que, a decir de Vicente Quirarte, el poeta escribió durante una breve estancia en la Ciudad de México en 1942. Este poema se basa en el libro homónimo de la Biblia y toma la anécdota amorosa de Booz y Ruth como su eje principal. La obra de Owen reivindica el relato bíblico como una historia de amor, por encima de sus atributos mesiánicos. En una carta dirigida a José Vasconcelos, el poema explica: “Éste [Libro de Rut] ha sido muy calumniado por nosotros los católicos, que lo tomamos como un simple registro genealógico que partiera de David a Nuestro Señor- como si ello fuese necesario. Naturalmente es, sobre todo, un libro de amor". ${ }^{7}$ Es así como fiel a su concepción de la historia, Owen escribe esta obra poética que ha sido calificada como "el poema de amor más hermoso que se ha escrito entre nosotros". ${ }^{8}$

El romance entre Booz y Ruth, los héroes owenianos, evoca a aquellos amores entre el otoño y la primavera, en donde un hombre maduro encuentra nuevos bríos en una bella joven, ya sea que estas pasiones tengan un desenlace fatídico o triunfal. En la literatura existen un sinfín de ejemplos de este tipo de amores, tales como la Lolita de Navokov o Juanita la Larga de Valera; de igual modo, en la Biblia está la historia del rey David y Abisag la sunamita y la que atañe a este trabajo, la de $\operatorname{Rut}^{9}$ la moabita pues, aunque en la Biblia no se especifica la diferencia de edad entre la pareja, se insinúa que

\footnotetext{
${ }^{7}$ Owen, ibid., pp. 288-289.

8 Evodio Escalante, "La experiencia poética de Gilberto Owen", La Jornada Semanal, https://www.jornada.com.mx/2005/09/04/sem-evodio.html, 04 de septiembre de 2005.

${ }^{9}$ En adelante, en el trabajo se emplea el nombre Rut cuando se hace referencia al libro bíblico y Ruth cuando se habla del personaje en el poema de Owen.
} 
él es mucho mayor que ella. Esta idea se mantiene en el poema de Owen con diversas imágenes o sutiles menciones como la del Fausto de Goethe. La fascinación por la juventud de la amada en el poema también se refuerza a través de la declaración del propio Owen en una carta de 1949 que escribe a Salvador Novo: "Yo vivo cinco días a cien grados en Filadelfia, y dos días de millonario en Allenhurst. Es una playa para menores de edad, en la que suelo repasar, de memoria, el Libro de Ruth". ${ }^{10}$ Vicente Quirarte incluso se ha aventurado más y ha insinuado que la inspiración del poeta viene directamente del amor que le profesaba a su sobrina Margarita, quien tan sólo tenía 18 años por aquel entonces en que su tío escribía el bello poema. La mención de estos datos cobra relevancia para el análisis del poema en cuestión, dada su cercanía al tiempo de composición y a su temática.

En resumen, el Libro de Ruth toma del relato bíblico de Rut la anécdota amorosa para construir el objetivo comunicativo del poema que será la experiencia del amor entre un hombre mayor y una joven, cuyo destino se adivina imposible e infructífero dada la diferencia de edad entre ambos. Los amantes son encarnados a través de los personajes mitológicos del judío Booz y Ruth la moabita, los cuales funcionan como máscaras que ocultan la identidad del "yo lírico" y de la amada. En no pocas ocasiones, los versos aluden a cuestiones biográficas del propio Owen. Bajo este supuesto se pueden identificar dos espacios dentro del poema, uno en el que resuena la voz del "yo lírico", ubicado en la modernidad del tiempo presente y otro espacio de representación en donde el "yo lírico", aparentemente, se esconde detrás de la máscara de Booz para atribuir a su experiencia amorosa la cualidad mítica de los grandes amores trágicos.

${ }^{10}$ Owen, op. cit., pp. 292-293. 


\section{La exégesis del libro bíblico}

Para un adecuado análisis del poema en cuestión es pertinente una breve aproximación al libro homónimo de la Biblia. Para empezar, cabe mencionar que la historia contada se sitúa antes del 110 a.C., en el tiempo de los jueces, periodo anterior a la monarquía y señalado como una época de hambruna en la tierra. El relato gira en torno a la tragedia de Noemí, una mujer israelita que, tras perder a su esposo Elimelec y a sus dos hijos Mahlón y Quelión, decide regresar a la tierra de Judá y despedir a sus dos nueras, Orfa y Rut. La primera regresa a su tierra, pero la segunda no quiere apartarse de su lado y hace un pacto con ella: “Tu pueblo será mi pueblo, y tu Dios mi Dios". ${ }^{11}$ En el segundo capítulo, Rut se propone ir a algún campo a recoger espigas para ella y Noemí. Respecto a esto, Deuteronomio muestra que ayudar a las viudas, huérfanos y extranjeros era una ley para el pueblo de Israel, ya que éstos representaban los grupos más vulnerables. ${ }^{12}$ Rut pide permiso para espigar en un campo y pronto conoce al dueño, un judío llamado Booz que resulta ser un pariente lejano de Elimelec, cuya responsabilidad es redimir a su familia para evitarles la desgracia, esto de acuerdo con la ley de Levítico. ${ }^{13}$ En el tercer capítulo Noemí pide a Rut que visite a Booz en la era y se le entregue para que así puedan asegurarse un porvenir, pero la sabia moabita prefiere apelar al lado moral de Booz, recordándole al hombre sus responsabilidades como pariente. Booz acepta con gusto, pero antes debe negociar con otro pariente más cercano a Elimelec para conseguir el derecho a redimir no sólo a Noemí, sino también a Rut a través de la ley del levirato. ${ }^{14}$

\footnotetext{
${ }^{11}$ Reina Valera, Rut, 1:16, 1960.

12 "Cuando siegues tu mies en tu campo, y olvides alguna gavilla en el campo, no volverás para recogerla; será para el extranjero, para el huérfano y para la viuda; para que te bendiga Jehová tu Dios en toda obra de tus manos". Ídem., Dt., 24:19.

13 "Cuando tu hermano empobreciere, y vendiere algo de su posesión, entonces su pariente más próximo vendrá y rescatará lo que su hermano hubiere vendido”. Ídem., Lev. 25:25.

${ }^{14}$ El propósito de esta ley era preservar el nombre y herencia de las familias: "Cuando hermanos habitaren juntos, y muriere alguno de ellos, y no tuviere hijo, la mujer del muerto no se casará fuera con hombre extraño; su cuñado se llegará a ella, y la tomará por su mujer, y hará con ella parentesco". Op.cit., Dt., 25:5.
} 
Hacia el final, el objetivo se logra y el pariente otorga su derecho a Booz a través de una vieja costumbre: "Había ya desde hacía tiempo esta costumbre en Israel tocante a la redención y al contrato, que para la confirmación de cualquier negocio, el uno se quitaba el zapato y lo daba a su compañero; y esto servía de testimonio en Israel". ${ }^{15}$ Así es como Booz redime a Noemí y se casa con Rut, quien le da un hijo al que llaman Obed, del cual desciende el rey David y el mismo Jesucristo.

De este último hecho se desprende el carácter mesiánico de la obra que es señalado y rechazado por el propio Owen. No obstante, numerosos estudios teológicos llaman la atención sobre este aspecto. Por ejemplo, Bernardeth Caero destaca el papel clave de mujeres extranjeras en los evangelios: "Estas mujeres, Tamar, Rajab, Rut, la mujer de Urias (Betsabe), a excepción de María tienen un origen extranjero. Según Zenger, a Rut se la presenta como la primera madre de Jesús y no hay que olvidar, que sin Tamar no hay Peres, sin Rut no hay David, sin Betsabé no hay Salomón y sin Rajab no existiría la historia de la conquista de la tierra". ${ }^{16}$ Ésta es la razón por que durante mucho tiempo se considerara la unión de Booz y Rut como una metáfora del casamiento entre Cristo y la Iglesia. Sin duda, la inclusión del Libro de Rut dentro del canon judeocristiano es un caso peculiar. La historia de una mujer extranjera y viuda que logra ser parte del pueblo elegido de Jehová gracias a su virtud se identifica más con una fábula moral o de aprendizaje. Por esta razón, su inserción en el canon a menudo se ha puesto en duda, no sólo por su temática, sino por las discusiones en torno al orden cronológico que debe ocupar. Por un lado, en la Biblia Hebrea este libro pertenece al conjunto de los Escritos o Hagiógrafos (Ketuvim), considerados como libros menores en comparación con los de los conjuntos de la Ley o Instrucción (Torá) y Profetas (Nevi’im). Por otra parte, en la Biblia de los

\footnotetext{
${ }^{15}$ Op.cit., Rut, 4:7.

${ }^{16}$ Bernardeth Caero, "¿La mano de una mujer? Aspecto histórico, género literario y teología del libro de Rut", ATUCSC, 12.1., 2010, pp. 91-103.
} 
Setenta, de la cual se desprenden las Biblias cristianas de hoy en día, el libro se sitúa después de Jueces, es decir, como parte del conjunto los Profetas. Este cambio en el orden ha sido justificado por el tiempo cronológico expresado en el primer versículo del libro: "Aconteció en los días que gobernaban los jueces, que hubo hambre en la tierra" ${ }^{17}$ y es un aspecto importante porque implica una interpretación de sentido distinta de acuerdo con la posición que se le asigne. ${ }^{18}$ Generalmente, los estudiosos concuerdan en que el Libro de Rut fue escrito entre los siglos V. - IV. a.C., época del postexilio, y que su propósito dentro del canon fue la validación de los matrimonios mixtos. Respecto a esto, Caero señala que este libro "critica la actitud rigorista del pueblo de Dios frente al extranjero, que había surgido por querer mantener su identidad religiosa" ${ }^{19}$ y que fue impulsada por los movimientos de Esdras y Nehemías, que estaban en contra de los matrimonios mixtos.

\section{Elementos míticos del poema}

Pero regresando al poeta mexicano, es claro que para Owen la elección del Libro de Rut como su fuente de inspiración de su poema responde a varias cuestiones relacionadas en su construcción, como a continuación se expondrá. En principio, el relato en sí otorga una mitología al romance trágico que se busca representar y sirve para poner en contexto la diferencia de edad entre los amantes, a la vez se les otorga a éstos ciertos atributos pertenecientes a los personajes bíblicos y se traslada la voz del "yo lírico" del espacio mítico al moderno. Antes que nada, hay que tomar en cuenta los aspectos de la historia que Owen decide destacar y excluir en su creación. Por ejemplo, la presentación de los hechos sigue una estructura muy similar, primero hay un momento de espera incierta

\footnotetext{
${ }^{17}$ Op.cit. Rut, 3:8.

${ }^{18}$ Rosa Yáñez, "El lugar del libro de Rut en el canon”, Ciencias religiosas, núm. 18.

${ }^{19}$ Caero, op.cit., p. 103.
} 
introductoria, seguido del encuentro, el clímax amoroso y el final, aunque éste tendrá un desenlace diferente, pues mientras que en la Biblia la resolución es la salvación y continuación de la vida, en el poema oweniano el único camino es la muerte. De igual modo, hay ciertos elementos puntuales que Owen selecciona para su poema; uno de ellos es el epígrafe, un extracto del relato bíblico que anuncia el eje central del poema, que será el encuentro erótico-sexual entre los amantes: "Y aconteció que, a la media noche, se estremeció aquel hombre, y palpó: y he aquí la mujer, que estaba acostada a sus pies". ${ }^{20}$ Cabe mencionar que en la Biblia no se alude como tal al encuentro sexual, pero se puede intuir que la visita de Rut tiene ese propósito, dadas las palabras de Noemí: “[...] no te darás a conocer al varón hasta que él haya acabado de comer y de beber", ${ }^{21}$ así como por la petición de Rut a Booz en la era: "Yo soy Rut tu sierva; extiende el borde de tu capa sobre tu sierva, por cuanto eres pariente cercano", ${ }^{22}$ pues tanto el verbo "conocer" como la frase "extiende tu capa" solían usarse como eufemismos del acto sexual o bien, del matrimonio. Respecto a Owen esta escena es puro erotismo y, de hecho, cada parte de su poema conducirá a la consumación del deseo carnal. La primera parte titulada "Booz se impacienta" corresponde a la espera del amante que aguarda la llegada de Ruth y es el equivalente al primer capítulo del libro bíblico "Noemí y Rut” que cuenta la llegada de ambas mujeres desde la tierra de Moab. En el poema de Owen, se menciona la llegada de la moabita a través de los versos: “deja el no ser de tu Moab incierta; / sal ya de ti. Mis pies están helándose". ${ }^{23}$ Estos versos, además de introducir a los personajes, guardan una estrecha relación con el epígrafe, son la fría antesala al clímax del encuentro amoroso. Tal como en el episodio bíblico, en esta primera parte del poema se menciona Moab, el pueblo originario de Rut que, de acuerdo con la Biblia, recibe este nombre del primer hijo

\footnotetext{
${ }^{20}$ Op.cit., Rut, 3:8.

${ }^{21}$ Ibid., 3:3.

${ }^{22}$ Ibid., 3:9.

${ }^{23}$ Owen, op. cit., p. 101.
} 
que Lot tuvo con una de sus hijas después de la destrucción de Sodoma y Gomorra. El nombre Moab posee entonces una carga negativa, no sólo es un pueblo extranjero y profano, sino un pueblo maldito, producto del incesto. En consecuencia, estas cualidades se asocian también a la Ruth creada por Owen, y anuncia la fatalidad presente en todo el poema. En tanto, el Booz de Owen adquiere dos cualidades importantes del personaje bíblico, la primera ocurre al ser nombrado como el "hijo pródigo" que en parte deriva de su carácter benevolente, pero también es un guiño a la parábola del hijo pródigo que se entrega a los placeres carnales. La otra cualidad es la edad, pues aunque Owen no presenta un Booz senil, sí se deduce que se habla de un hombre maduro como el de la Biblia. ${ }^{24}$ Esto a través de ciertas referencias, por ejemplo, cuando en la tercera parte del poema Booz canta: "cómo temer tus años, si me dabas / toda mi juventud en mi deseo", ${ }^{25}$ así también se le identifica como un Fausto que persigue a la joven amada y con el Booz anciano del famoso poema de Víctor Hugo "Booz dormido", aunque Owen advierte que su Booz no es “el durmiente que sueña un cedro Huguiano". El suyo es un amante que encuentra su triunfo en la derrota estéril de su amor.

La segunda parte del poema lleva por título "Booz encuentra a Ruth” y es la que hace referencia al episodio en donde Rut recoge espigas en el campo de Booz. Owen escribe: "Tras un viento que trae amantes olvidados que se encuentran de pronto en los lugares más insólitos". ${ }^{26}$ Estos versos nos dicen mucho de Ruth, aunque su historia no sea en este caso protagónica, Owen no olvida plasmar su viudez y su condición como extranjera. Más adelante se menciona: “[...] y que luego te humilla a recoger espigas desdeñadas”. Esta es la Rut moabita, aquella que aun siendo extranjera se ampara en las

\footnotetext{
${ }^{24}$ En la Biblia encontramos: "Y él dijo: Bendita seas tú de Jehová, hija mía; has hecho mejor tu postrera bondad que la primera, no yendo en busca de los jóvenes, sean pobres o ricos". Op.cit., Rut. 3:10.

${ }^{25}$ Owen, op.cit., p. 102.

${ }^{26}$ Ibid., p. 101.
} 
leyes del pueblo judío para conseguir comida para ella y su suegra. No obstante, como más adelante se revisará, la elección de este personaje en el poeta no es gratuita, sino que responde a motivos específicos, la Ruth de Owen representa a "el otro", es decir, el ser amado en cuyo cuerpo se experimenta la trascendencia. Finalmente, la tercera parte "Booz canta su amor" es el encuentro amoroso-sexual entre los amantes, el anunciado en el epígrafe y que alude a la visita de Rut a Booz en la era.

En resumidas cuentas, el poema de Owen rescata al menos tres episodios del libro bíblico. Estos son: 1) la llegada de Ruth, 2) el encuentro en el campo 3) el encuentro amoroso-sexual. En cuanto al final, Owen agrega dos últimas partes a su poema, siendo la cuarta "Booz ve dormir a Ruth", que reemplaza la parte del matrimonio por la contemplación erótica del amante y la quinta titulada "Celos y muerte de Booz", que eclipsa el nacimiento de Obed por el desenlace fatídico y sin esperanza del hijo pródigo. 


\section{LA MÁSCARA Y LA REPRESENTACIÓN EN EL POEMA}

\section{Los usos de la máscara}

El mito es una característica fundamental en la obra de Owen que viaja a través de la mitología oriental, griega y judeocristiana buscando personajes en los cuales reflejar su propio espíritu anhelante de universalidad, pero también poseedor de una sed insaciable por encontrarse a sí mismo y comprender la sustancia del hombre moderno. Al igual que el resto los poetas del Grupo Sin Grupo, Owen tiene predilección por las figuras heroicas. A decir de Vicente Quirarte, los Contemporáneos crearon su propio héroe pues, aunque celebraron a Ulises y Sindbad "la admiración no estaba dirigida a la idea arquetípica e inmutable de los héroes. Se trataba más bien de traducirlos, de descifrar las señales que sus luces les enviaban a través del tiempo". ${ }^{27}$ Por su parte, Sheridan pone énfasis en la elección de Ulises como nombre de la primera revista del grupo: "De ahí su nombre: Ulises, que algo tiene de soledoso, de aislamiento, de voluntad personal, de ingenio y, sobre todo, de conciencia del desastre. Es la mitología del viajero a que nos hemos referido antes, del buscador compulsivo, del curioso inagotable" 28 , y comenta que la "triada tricultural de la nueva curiosidad" de los Contemporáneos son Ulises, Sindbad y el Hijo Pródigo.

El héroe contemporáneo es heredero del Romanticismo en cuanto encarna la contradicción humana y la crisis de identidad que surge al enfrentarse a una modernidad en donde la realidad se vuelve cada vez más inaprensible y en donde las guerras han legado una existencia desesperanzadora para el hombre moderno. Owen refleja este mismo sentir en su obra a través de la figura del héroe venido a menos y presenta un

\footnotetext{
${ }^{27}$ Vicente Quirarte, El mito, la máscara y el monólogo: el discurso amoroso de Gilberto Owen, Tesis de maestría, México, UNAM. 1989, p. 103.

${ }^{28}$ Sheridan, op.cit. p. 281.
} 
"héroe ambiguo, dinámico, cubista, condenado a descifrar permanentemente los enigmas de su personalidad múltiple. Nagual versátil, héroe de las mil caras, es capaz de transmutarse en Jacob, Ulises o Jesucristo". ${ }^{29}$ De tal modo, la reelaboración de los héroes escogidos por Owen por un lado otorga al "yo lírico" la capacidad de un sentir universal y, por otro, es reflejo de la crisis del hombre moderno y del propio Owen que, impedido de la experiencia heroica, sólo tiene la búsqueda interior. Para J. Whittingham en Owen se revela "la necesidad de la ilusión de la máscara para dar forma y expresión a la ambigüedad de lo informe", pero su uso es diferente de las máscaras apropiadas por un personaje que sólo busca despistar al lector. ${ }^{30}$ En este punto conviene recordar la reflexión de Guillermo Sucre respecto al uso de la máscara en la poesía hispanoamericana:

La multiplicidad de personas elocutivas se inicia también con los poetas (Apollinaire). Los poemas de Pound o Eliot son verdaderas creaciones dramáticas, en el sentido teatral del término: personae (máscaras) independientes del autor, que tienen su propia voz y su propio destino. No otra cosa es lo que hace Fernando Pessoa a través de sus "heterónimos", aunque con esta variante: sus personajes son poetas creados. "Máscaras, agonías, resurrecciones / destejerán y tejerán mi suerte", dice Borges en un poema, hablando con la voz de Browning, que es también una manera de hablar del otro Borges. Metamorfosis del yo que son creadas por el lenguaje mismo: fueron también los poetas los primeros quizá en intuir este poder verbal. Uno dice soy éste, ése o aquél, y ya con sólo enunciarlo en palabras se deja de serlo, advertía Pound. ${ }^{31}$

Con lo anterior es posible entender el desdoblamiento que Owen realiza a lo largo de su poesía, empleando las máscaras de héroes mitológicos en los cuales refleja sus preocupaciones como poeta y como hombre, creando no sólo su mundo poético, sino una mitología de su propia vida. Respecto a esto, Belén Hernández señala que Owen somete a su obra a la reelaboración poética de datos autobiográficos. "En ella los motivos más recurrentes son la ausencia de un nombre o bien la usurpación de su nombre por otros,

\footnotetext{
${ }^{29}$ Quirarte, op.cit., p. 109.

${ }^{30} \mathrm{~J}$. Whittingham Georgina, "La función de la ironía y de la crítica contemporánea en Gilberto Owen”, Texto crítico, 1990, p. 22. Disponible en: http://cdigital.uv.mx/handle/123456789/7204.

${ }^{31}$ Guillermo Sucre, La máscara, la trasparencia ensayos sobre poesía hispanoamericana, México, FCE, 2001, p. 127.
} 
referencia al nacimiento espurio de Owen". ${ }^{32}$ Por su parte, Claudio Vázquez menciona que las investigaciones bibliográficas sobre Gilberto Owen a la fecha siguen siendo insuficientes, en tanto que casi todas se han centrado en periodos específicos de su vida o bien porque se tiende a mezclar la vida del poeta con su literatura. ${ }^{33}$ Aunque en menor medida que en otras de sus obras, Libro de Ruth también contiene referencias autobiográficas que, además de remitir directamente al autor, marcan una ruptura con la construcción del espacio mítico del poema, puesto que se insertan en el espacio de la modernidad.

Owen realiza la desmitificación y desacralización del relato bíblico de Rut, que suele ser estudiado como una enseñanza de esperanza, fe y fidelidad a Dios, para narrar el fracaso amoroso de Booz, personaje que es construido a partir de la imagen del héroe venido a menos, en contraste con el del relato bíblico que es engrandecido a través de la unión con Ruth. El Booz de Owen es concebido como el amante heroico porque se entrega sin temor a la experiencia del amor, aún a sabiendas de que esta será su perdición y lo conducirá a su propia muerte. Si bien en el poema es posible notar que Booz es la voz protagonista, el título del poema nos confirma que el personaje de Ruth es igual de importante, aunque su voz no aparezca en el poema, su presencia se manifiesta en la ausencia y es esto lo que la hace tan fuerte. Lo cierto es que Owen ya había aludido a este personaje para dedicar versos a una amada joven en "Regaño del viejo": “(A veces, Ruth, a veces, /sin tu fluvial tersura aquí, a mi lado, / mis nervios gritan y se rompen en esdrújulas"). ${ }^{34}$ Este poema refuerza la lectura de una relación marcada por una diferencia significativa de edad.

\footnotetext{
${ }^{32}$ Belén Hernández, "Feliz quien como Sindbad ha hecho un largo viaje (El viaje intertextual de Gilberto Owen)" en El largo viaje de los mitos: Mitos clásicos y mitos prehispánicos en las literaturas latinoamericanas, Roma, Sapienza Universita Editrice, 2020, p. 133.

${ }^{33}$ Claudio Vázquez brinda un acercamiento actualizado a la biografía del poeta en Gilberto Owen. Dos encuentros, México, UNAM, 2015.

${ }^{34}$ Owen, op.cit., p. 97.
} 
La historia de amor fatídico entre Booz y Ruth cobra, en no pocas ocasiones, tintes autobiográficos. Bajo este supuesto se pueden identificar dos espacios dentro del poema, uno que pertenece al "yo lírico", ubicado en la modernidad del tiempo presente y en el que se logra distinguir la presencia del propio Owen, y otro espacio de representación, en donde el "yo lírico" se transmuta en Booz y desarrolla la historia de amor mítico. Para tener clara esta separación conviene hacer las preguntas ¿Quién habla en el poema? Y ¿a quién se dirige el poema?, ya que las respuestas a estos cuestionamientos muestran las diferencias entre el mito y la creación poética. Por ejemplo, en apariencia el poema está dirigido a Ruth, pero sabemos que el destinatario es alguien más cercano a la realidad del poeta. La segunda parte, “Booz encuentra a Ruth”, será ilustrativa de esta separación entre el espacio de la representación y el de la modernidad.

Traes un viento que mueve los rascacielos más tercos y que te ciñe para mostrarme cómo fue la cabeza de la Victoria de Samotracia, Y que luego te humilla a recoger espigas desdeñadas. ${ }^{35}$

En estos versos se pueden identificar imágenes relacionadas con la modernidad, tales como los rascacielos y la mención a la Victoria de Samotracia, en la que bien podemos encontrar un guiño a las vanguardias europeas. Si los futuristas encuentran en la máquina una nueva belleza, Owen mantiene un estatuto clásico al encontrar la belleza en la contemplación de la mujer amada. A la par, también aparece la imagen del campo de espigas que alude al episodio bíblico y al personaje de Ruth. La estructura métrica de esta segunda parte también nos habla de una coexistencia entre la tradición y lo contemporáneo. En apariencia puede pensarse que esta segunda parte está formada por versos libres que rebasan las 14 sílabas poéticas e incluso se puede emprender una lectura como tal, pero no sin reparar pronto en que la misma dicción del poema obliga a realizar cesuras exactas que determinan la medida de versos. Un análisis más profundo revela

\footnotetext{
${ }^{35}$ Ibid., p. 101.
} 
que si bien en los versos de Owen no existe un metro fijo, ni un orden claro de las pausas, éstos sí están estructurados a partir de patrones acentuales que coinciden con versos utilizados en la tradición, tales como el alejandrino o el endecasílabo. Lo anterior se puede ejemplificar bien en los siguientes versos, que se reproducen fielmente de la edición impresa:

Traes un viento que traer amantes olvidados que se encuentran de pronto en los lugares más insólitos como gaviotas en la nieve de los volcanes. ${ }^{36}$

A simple vista la lectura sugiere que nos encontramos ante un ejercicio de verso libre, pero si miramos bien encontraremos una reunión de alejandrinos: "Traes un viento que traer amantes olvidados (14) / que se encuentran de pronto en los lugares más insólitos (14) /como gaviotas en la nieve de los volcanes (14)". A su vez, la lectura de estos versos sugiere una clara prominencia prosódica, pues es evidente que la cesura entre los versos responde a una intención de dicción más natural que la que en apariencia plantea el texto. En los versos posteriores de nuevo se encuentra la contraposición entre modernidad y mito en las imágenes presentadas:

Y es nacer a la muerte que acecha en los festines (14) / de un octubre sin fin y sin castigo, (11)/ una muerte que desde mí (9) / te acecha en las ciudades y en las horas (11) / y en los aviones de cien pasajeros (11).

Fausto que te persigue desde el episodio fatal de la siega en mis manos nudosas y tiernas de asesino. ${ }^{37}$

Tal como se indica arriba con las diagonales es posible observar un predominio del endecasílabo y del alejandrino, pese a que la presentación visual que elige Owen parezca verso libre. Es clara la lógica del encabalgamiento, por ejemplo, en el endecasílabo: "de un octubre sin fin y sin castigo", como también lo es la irrupción de las cesuras entre los versos, para ello basta hacer una lectura pausada y notar las correspondencias. Pese a esto, la apertura de la estructura y presentación de los versos de

\footnotetext{
${ }^{36}$ Loc.cit.

${ }^{37}$ Loc.cit.
} 
Owen puede dar pie a diversas interpretaciones de forma y, en ocasiones, incluso de sentido. ¿Qué intención tiene esto?, Superficialmente quizás se puede hablar de una intención unificadora del fondo y la forma, cuyo propósito es la unidad entera del poema. De ser así, correspondería al lector la tarea de desnudar los versos para encontrar qué hay detrás de ellos. La coexistencia de una poesía construida en versos tradicionales, pero con prominencia prosódica, remite a su vez al desdoblamiento entre la voz del "yo lírico" y la representación de Booz que, en los versos finales de esta segunda parte, se identifica como el Fausto que acecha a la amada, esto da pie a que la presencia de la muerte y la fatalidad se anuncien cada vez con mayor claridad. Esta parte cierra con el verso pentadecasílabo: "Huye de mí, (5) / que soy elvientoeldiablo que te arrastra (11)”. El subrayado en la sinalefa posee un sentido prosódico, lírico y de contenido, pues es literalmente un arrastre sonoro y visual de palabras.

\section{La revelación de los amantes}

A lo largo del poema la presencia de Booz y Ruth se mantiene fuerte, sobre todo a través de los subtítulos que aluden directamente a ambos personajes, pero poco a poco se realiza la desmitificación a través de las menciones a la modernidad y lo autobiográfico. Owen elige a Booz, aquel hombre que en la Biblia es descrito como un hombre piadoso que remide y salva a la mujer extranjera, y lo desmitifica en la poesía para mostrar a un amante vencido por la pasión ante la moabita. Si bien todos los subtítulos del poema aluden a la máscara Booz, en los versos quien habla impaciente es el "yo lírico" y se identifica a sí mismo con el "hijo pródigo". En los siguientes versos la máscara de Booz desaparece y queda sólo la voz del "yo lírico" que aguarda la llegada de su amada. Su voz surge en la noche moderna y solitaria: "Pasan sin nadie todos los tranvías. / Su huracán no de 
esperanzas no para en las esquinas de mi cuerpo". ${ }^{38}$ Por otra parte, en el caso de Ruth es más fácil identificar la separación con la amada aludida por Owen, ya que esta última se asocia con los elementos de la modernidad y tiene una mayor exposición al ser el destinatario del poema, a diferencia del "yo lírico" que llega a perderse y confundirse detrás de la máscara de Booz. La tercera parte "Booz canta su amor", quizás por representar el clímax del poema, es la que mejor revela a los amantes, dejando por un momento las máscaras de lado. En la estructura rítmica se observa un mayor lirismo. Su mismo nombre indica que se trata de un canto. Su forma recuerda al romance tradicional, sólo que en lugar de octosílabos está conformada por endecasílabos con rima asonante en los pares. Como se muestra en el siguiente ejemplo, la rima cae en freno/deshielo, merezco/duelo, gesto/deseo:

Me he querido mentir que no te amo, Roja alegría incauta, sol sin freno En la tarde que sólo tu detienes, Luz demorada sobre mi deshielo. Por no apagar la brasa de tus labios Con un amor que darte no merezco, por no echar sobre el alba de tus hombros Las horas que le restan a mi duelo. Pero cómo negarte mis espigas Si las alzabas con tan puro gesto; Cómo temer tus años, si me dabas Toda mi juventud en mi deseo. ${ }^{39}$

Esta constante permanece en las tres estrofas siguientes que completan un total de 40 versos. Se observa también un predominio de endecasílabos melódicos $(3,6,10)$ y sáficos $(4,8,10)$ que se mezclan entre sí, y uno que otro endecasílabo heroico $(2,6,10)$, que en conjunto otorgan a esta tercera parte el carácter melódico de un canto. En cuanto al contenido, aquí los amantes se liberan de las máscaras y se abren uno al otro. Es tanta la apertura que incluso es posible identificar al poeta detrás de ellos. Por ejemplo, el verso "París cumple en tu rostro quince años" remite a una carta escrita por Owen a Clementina

${ }^{38}$ Owen, op. cit., p. 100.

${ }^{39}$ Ibid., p. 102. 
Otero en 1928: "Tengo por usted quince años y el mundo es tan joven como yo. Soy, y ya no me avergüenza, romántico y tonto para usted, y la amo más que a mi vida, a la que por usted comprendo amable". ${ }^{40}$ Además, en esta parte aparecen dos nuevas máscaras míticas, la de Dafnis y Cloe, que representan el grado de intimidad de los amantes, así como el rejuvenecimiento de Booz a través de su contacto con Ruth. En tanto, en la cuarta parte "Booz ve dormir a Ruth", comienzan a aparecer de nuevo las referencias bíblicas que opacan la presencia real de los amantes. Otra referencia de cercanía autobiográfica es “Zirahuén era así dulce como su nombre:”, lugar que aparece constante en la obra poética de Owen y de donde su madre era originaria. En los últimos versos, la unión de los amantes antes proclamada se muestra como una imposibilidad, pues la amada pasa de identificarse con lo erótico a ser un ser inalcanzable envuelta en "sudarios de inocencia". Esto da pie a la quinta parte "Celos y muerte de Booz”. La culminación del poema es la revelación del amor infructuoso, la máscara vuelve a aparecer para recordar que no se trata del Booz bíblico ni del Booz Huguiano, sino del Booz oweniano que sabe, desde muchos versos antes, la esterilidad de su unión con Ruth y que carga con la culpa de tomar la juventud de la amada para sí: "y no podrás correr al amor de tu edad que he suplantado". ${ }^{41}$ Finalmente, Booz reconoce que no es posible prolongarse a través del cuerpo de la amada, "Ya no me vivo en ti", dice apenado, pues entiende que lo único que posee es la muerte: "Mi noche es alta y mía".

El final del poema es un retorno, si se toma en cuenta que desde el inicio se presentaron dos elementos importantes: la imagen de la noche relacionada con la muerte, “doblarán las doce de la noche", en el sentido de "doblar campanas" y el Caos como fuerza operante que altera el mundo del "yo lírico". La muerte de Booz entonces es algo

\footnotetext{
${ }^{40}$ Gilberto Owen, Me muero sin usted, cartas de amor a Clementina Otero, México, Siglo XXI Editores, 2004, p. 56.

${ }^{41}$ Owen, op.cit., p. 105.
} 
que se anuncia desde el principio y que sucede al final del poema. En la estructura también es posible observar esto, ya que la última parte retoma un metro muy similar al de la primera, una composición de heptasílabos, eneasílabos, endecasílabos y alejandrinos. Incluso hay una imagen que alude a la intención cíclica del poema:

Ya me hundo a buscarme / en un te amé que quiso ser te amo, $(7+11)$ donde se desenrolla un caracol atónito (14) / al descubrir el fondo salobre de sus ecos, (14). ${ }^{42}$

\section{El amante vencido ante la amada}

A lo largo de la obra de Owen la mujer erótica y el héroe derrotado son motivos recurrentes. Su universo poético está poblado de gorgonas peligrosas, Evas tentadoras y heroínas esquivas a sus versos. Las mujeres que fascinan al poeta son aquellas que lo retan con su seducción, ante las cuales se deja seducir y abatir. No es casual su predilección por héroes venidos a menos, tal como refleja la creación de un Perseo vencido por Medusa o un Sindbad varado que se abandona en los brazos de las peligrosas sirenas. Se puede decir que hay entonces una lógica en la cual, para Owen, el amante es vencido por la fuerza, seducción y sexualidad de la amada. Esta pasión también se ve reflejada en su vida, pues con la publicación de sus cartas personales se dio a conocer la devoción que tuvo por la actriz Clementina Otero, que conoció en 1928 en el Teatro de Ulises y con quien protagonizó El peregrino de Charles Vildrac, obra en la cual Otero representó a Dionisia, una joven que es instruida sentimentalmente por su tío Desavesnes, interpretado por Owen en la puesta en escena. De abril a noviembre de ese mismo año, Owen escribió sin descanso a Otero, aun cuando tuvo que partir a Estados Unidos para cumplir con sus labores diplomáticas. En estas cartas, el poeta muestra una pasión desbordada y otras tantas cae en la desesperación al no ser correspondido por su amada. En una carta fechada en julio de 1928 le escribe: "Alguna vez me he puesto a pensar

\footnotetext{
${ }^{42}$ Loc.cit.
} 
angustiado, en lo espantoso, en lo monstruoso que sería un noviazgo entre nosotros. Cruzo los brazos y la toco excesivamente dura y en punta, y yo tan blando que la vergüenza me golpea en lo único firme, mi amor a usted". ${ }^{43}$ En esta escritura se muestra la expresión del poeta al hablar con la amada; por ejemplo, a partir de imágenes en las que no teme exponer su fragilidad frente a ella; Owen atribuye a Clementina cualidades de firmeza, mientras que para él conserva sólo la "blandura" y la "vergüenza". La mención de las cartas de amor de Owen es importante porque encierra parte de su visión poética, desde su predilección por la imposibilidad del amor ligada a la exploración del erotismo y la representación del héroe vencido ante la seducción de la amada. Tampoco es casual que su recopilación más conocida lleve por título Perseo vencido (1948), nombre que surge precisamente bajo el tema de la mujer erótica que vence al amante. Respecto a esto, Owen explica en una carta dirigida a Luis Alberto Sánchez:

Dime si te parece bien el nuevo plan del libro, cuyo título, en ese caso, sería Perseo vencido; si no quieres añadirle la Ruth y el Madrigal, puede ser, como decía antes, Sindbad el varado. El Perseo me suena más, porque el origen de todo, el Madrigal, lo escribí viendo una de las innumerables estatuas, pensando que Medusa después de todo no había sido decapitada, y que seguía petrificando, a los que creemos vencerla, a través de la historia del arte. Y de la poesía. ${ }^{44}$

En sus cartas el poeta también muestra cierto rechazo hacia la idea de concretar la relación amorosa, como si lo motivara más la imposibilidad del amor: "Yo nunca tendré prisa y no me importa que no me ame desde ahora. Sería un matrimonio sólo para tenerla cerca de mí y conquistar poco a poco su cariño, que Amor es una casa que yo tendría que hacer ladrillo tras ladrillo". ${ }^{45}$ La predilección de Owen por los amores imposibles e infructuosos será una constante en su escritura y responde en gran medida de la visión romántica del amor en Occidente que Denis de Rougemont define como "aquello que nos hiere y nos anonada por su triunfo", es una visión en la que el dolor amoroso es un medio

\footnotetext{
${ }^{43}$ Owen, op.cit., p. 59.

${ }^{44}$ Ibid., p. 279.

${ }^{45}$ Ibid., p. 133.
} 
privilegiado de conocimiento total del mundo y de uno mismo que, en el fondo, encierra un gusto reprimido por la muerte y el obstáculo. ${ }^{46}$ Lo anterior se explica como una actitud de derrota ante el amor por parte del amante que es, a su vez, un anhelo por la muerte del "yo", la cual sólo se puede experimentar en la entrega total hacia el otro, es decir, la dialéctica del Eros, sobre la cual Rougemont dice que "introduce en la vida algo enteramente extraño a los ritmos de la atracción sexual: un deseo que ya no recae, que nada puede satisfacer, que rechaza y rehúye la tentación de cumplirse en nuestro mundo porque sólo quiere abrazar el todo. Es el sobrepasarse infinito, la ascensión del hombre hacia su dios. Y este es movimiento sin retorno". ${ }^{47}$

${ }^{46}$ Denis de Rougemont, El amor y Occidente, Barcelona, Kairos, 1993, p. 52.

${ }^{47}$ Ibid., p. 63. 


\section{LA DIMENSIÓN ERÓTICA DEL POEMA}

La dimensión del erotismo en el "Libro de Ruth" se divide en dos espacios, el de la transgresión y el de la muerte. Como antes se ha mencionado, el rechazo de Owen hacia la versión cristiana de la historia bíblica que da nombre a su poema instaura ya una transgresión hacia lo establecido que cobrará mayor fuerza en el desarrollo erótico del poema. Alfredo Rosas comenta respecto a la labor poética de Owen: "Su poesía es una invitación y una provocación para pensar en lo prohibido: "Si las personas que te rodean — dice- carecen del sentido del pecado, uno exalta sus signos". Él no habla de los pecados, sino que sólo exalta sus signos, a fin de que los leamos entre líneas”. De allí, explica Rosas, se desprende la dificultad y el misterio de muchas de las imágenes poéticas del poeta, sobre todo en relación con el mal y el eros. ${ }^{48}$

En el "Libro de Ruth" se observa un discurrir de la muerte de principio a fin, puesto que Owen posiciona al Caos como fuerza regente en el poema desde los primeros versos y, además, anuncia el destino fatal del hijo pródigo hacia la media noche. En este inicio hay también una voluntad transgresora de aquel mismo Owen que escribió: "Dios no está, existe. Llegó después del Caos, y morirá cuando el Caos vuelva a estar en todas partes” y sobre el cual Alí Chumacero señala:

Algo terrible tiene esta afirmación en pluma de un creyente, pero a la vez nos ayuda a considerar una idea extrema, ávidamente literaria, derivada de una concepción expresa en su poesía. Puesto que Owen pensaba que el tiempo arrasa con todo, para ser consecuente con esta creencia se veía obligado a insertar bajo la fuerza de ese alud al Dios en que creía. ${ }^{49}$

Si bien lo anterior no es propiamente un atentado contra la fe de Owen, sí revela que compartía, al igual que todos los Contemporáneos, una obsesión por la incontenible

\footnotetext{
${ }^{48}$ Alfredo Rosas, "Emily Dickinson y Gilberto Owen: ese par de perversos", La Colmena, núm. 63, 2009, pp. 28-36.

${ }^{49}$ Alí Chumacero, op. cit., p. 10.
} 
fuerza del tiempo y, más aún, una fascinación por la muerte entendida como el principio y fin de todas las cosas. En el Libro de Ruth Owen explora el extremo del erotismo al presentar la unión de los amantes bíblicos a partir de un juego de seducción en donde el "yo lírico" se vulnera entregando todas sus armas a fin de obtener la misma rendición por parte de la amada. El poema entonces desarrolla la unión sexual de los amantes bíblicos a partir de la experiencia erótica, lo que permitirá no sólo un alejamiento del mito religioso, sino una transgresión de las normas de la sexualidad bíblica que se expresará a través del lenguaje erotizado en el poema. Asimismo, la unión erótica se expone como un acto de entrega total que da paso a la continuidad del ser y que culmina con la disolución del "yo individual" en un acto que se equipara a la muerte. Lo anterior será estudiado más a fondo a partir de las categorías de "continuidad" y "discontinuidad" postuladas por George Bataille en L'Erotisme. De tal modo, el poema se desarrolla a partir de dos elementos complementarios y constitutivos de la dimensión de Eros, la transgresión y una pulsión constante de la muerte.

\section{El amante como seductor}

La sexualidad en Libro de Ruth corresponde a la iniciación del ritual erótico. En la primera parte, la espera de Booz constituye la recreación de la amada a través de la ausencia, que en el poema se traduce como una erotización del lenguaje a través de una sucesión de imágenes y metáforas. En la consumación del acto sexual, que tiene lugar en la tercera parte del poema, sobresale la virilidad de Booz y la apertura del cuerpo de Ruth: "Vámonos como siempre: Dafnis, Cloe. / Tiéndete bajo el pino más erecto, / una brizna de yerba entre los dientes. / No te muevas. Así. Fuera del tiempo”. Aquí la imagen del Booz senil ha quedado atrás, la edad ya no es un abismo entre los amantes, puesto que el acto sexual los iguala. Ahora el "yo lírico" no es el viejo Booz, sino un rejuvenecido Dafnis que juguetea con su amada Cloe. Anteriormente, ya se había referido al uso de la 
máscara en la poesía de Owen, y la función que ésta cumple como un recurso que da pie a la reelaboración de los mitos y a la transformación de figuras legendarias como Sindbad, Perseo o Booz en héroes venidos a menos, cuyo objetivo es la identificación de éstos con el "yo lírico" que suele encarnar al amante vencido. No obstante, en la dimensión del erotismo es preciso observar cómo el uso de la máscara se vuelve parte del juego de seducción emprendido por el amante que, en un principio, parecía vencido e impotente ante la amada. Esta insinuación también se hace presente a través de la equiparación del "yo lírico" en menciones como: "Fausto que te persigue" y "Huye de mí, que soy elvientoeldiablo que te arrastra". El "yo lírico" en el poema no es ya el héroe vencido por la pasión amorosa, pero tampoco es el héroe conquistador, sino que su papel es el del seductor que encuentra en la derrota su propio triunfo. Tomás Segovia bien supo ver este atributo en Owen, de quien comenta: "Ya dije que juega a perder, pero a perder de cierta manera. Su estrategia es la entrega desarmante. Su figura simbólica es el desnudamiento" y más adelante señala: "la seducción se arma exclusivamente para entregar las armas, a fin naturalmente de que el otro entregue las suyas. Seducir es entregarse a la entrega del otro y buscar su entrega a la nuestra". ${ }^{50}$ No obstante, cabe señalar que el juego de seducción de Owen no consiste en el engaño a la manera del famoso burlador de Sevilla, ya que la seducción que emplea el poeta no busca la conquista, sino que rechaza toda posible victoria y se muestra vencido desde el principio ante la amada.

Al igual que Segovia, Baudrillard entiende la seducción como un acto de vulnerabilidad: "Seducir es fragilizar. Seducir es desfallecer. Seducimos por nuestra fragilidad, nunca por poderes o signos fuertes. Esta fragilidad es la que ponemos en juego en la seducción y la que le proporciona esta fuerza. Seducimos por nuestra muerte, por

\footnotetext{
${ }^{50}$ Tomás Segovia, Cuatro ensayos sobre Gilberto Owen, México, FCE, 2001, p. 78.
} 
nuestra vulnerabilidad, por el vacío que nos obsesiona". ${ }^{51}$ Asimismo, atribuye a la figura del seductor un único objetivo, el de seducir a la joven que, a diferencia de él, posee un estado de privilegio y gracia: "El seductor tiene como vocación exterminar esta fuerza sobrenatural de la mujer o de la joven con una maniobra deliberada que igualará o superará la otra, que contrarrestará con una fuerza artificial igual o superior la fuerza natural a la cual, contra todas las apariencias que hacen de él el seductor, ha sucumbido desde el principio". ${ }^{52}$ Es por ello que el canto de Booz a Ruth comienza con versos que expresan la negación de lo que realmente se anhela: "Por no apagar la brasa de tus labios / con un amor que darte no merezco, / por no echar sobre el alba de tus hombros / las horas que le restan a mi duelo", aquí lo que se niega, se afirma, en tanto se sabe que el anhelo de "yo lírico" es poseer a la amada. En las siguientes estrofas, el "yo lírico" cambia el tono frágil de su discurso por uno más imperativo que se refleja en el uso de formas verbales como: quédate, óyela, vámonos y tiéndete, que conducen a la consumación del acto sexual.

No obstante, en la siguiente parte el "yo lírico" expresa que su unión con Ruth resulta imposible. Esta imposibilidad del amor se desprende del mismo orden de la seducción, puesto que es el seductor quien desde el principio se ha propuesto la derrota. “El seductor es nómada. Cuando el objeto de su pasión se vuelve accesible, es tiempo de cambiar de territorio. La partida es el antídoto infalible contra la muerte de morirnos en el otro". ${ }^{53}$ A la luz del Libro de Ruth, según explica Quirarte, la huida representa el único medio para ganar y es por lo que la última parte del poema titulada "Celos y muerte de Booz" es una exclamación antitética que en realidad busca la permanencia, no la muerte:

Me voy para que seas feliz, para que no sufras, para que no me veas llorar. Debajo de esas palabras, late un mensaje que dice exactamente lo contrario: me voy para que te sientas

\footnotetext{
${ }^{51}$ Jean Baudrillard, De la seducción, Madrid, Cátedra, 1981, p. 80.

${ }^{52}$ Ibid., p. 95.

${ }^{53}$ Quirarte, op.cit., p. 170.
} 
infeliz, para que sufras, para que me veas llorar. En el discurso del que parte, no hay más dolor que el propio. Todo amante que enuncia el discurso de partida hace exclusivo el duelo, aunque el otro sea quien activamente abandona. ${ }^{54}$

Detrás de la huida de Booz existe la intención de permanecer en la memoria de Ruth a través de su ausencia. De este modo, aunque Booz se despide en una aparente derrota al darse cuenta de que la unión con Ruth resulta imposible, en el fondo su retirada es su forma de ganar en tanto sabe que es él mismo quien pone el obstáculo para la conquista y no la amada quien se aparta de él. Esto puede verse reflejado en los versos: "y no podrás correr al amor de tu edad que he suplantado" o "Te cedo mi lámpara vieja por la tuya de luz de plata virgen", en este final Ruth es quien parece perder más, aunque sea Booz quien se retira a morir.

\section{Sobre la transgresión en el poema}

La experiencia del erotismo implica siempre una superación de lo prohibido en cuanto representa un acto de apertura total hacia el otro. Desde el discurso patriarcal de la Biblia la sexualidad humana es vista, en su mayoría, sólo con fines de reproducción; sin embargo, el erotismo surge como una fuerza diferente en donde la sexualidad no está al servicio de la procreación, sino del mismo placer. En Libro de Ruth Owen mantiene una actitud irónica al titular su poema de manera homónima a la obra bíblica, toda vez que la suya es de carácter erótico. En el poema la transgresión tiene lugar desde el mito, en tanto que la unión entre Booz y Ruth se opone a la prohibición judía sobre los matrimonios mixtos, no obstante, Owen va un paso más allá al plantear una unión sexual que prescinde de la aprobación de la ley judía y, más aún de la ley del matrimonio. Además, en principio Ruth no es asociada a la virtud, sino a nombres malditos como Moab o Babel, así como a una condición de esterilidad. Otra transgresión es la concepción del cuerpo de Ruth

\footnotetext{
${ }^{54}$ Loc.cit.
} 
como vía a la plenitud del ser, esto se expresa en los versos: "Por la carne también se llega al cielo", esto es la visión del ritual erótico como una experiencia de éxtasis en donde se borran las barreras entre los cuerpos y se logra acceder a una continuidad del ser más allá de la experiencia terrenal y cuyo fin representa un regreso a la consciencia sobre la finitud de la vida: "Si cerrara los ojos, despertándome, / me encontraría, como siempre, muerto". 55

Posterior al encuentro entre los amantes lo que sigue es la contemplación erótica del cuerpo de Ruth por parte de Booz. En la cuarta parte del poema Ruth pasa de ser la mujer sexual a ser la mujer inaccesible cuyo cuerpo "prolonga su blancura en el cielo / como el halo de las tehuanas y los santos", ${ }^{56}$ hasta convertirse hacia el final en una mujer envuelta "en sudarios de inocencia". No obstante, pese a las imágenes religiosas, Owen mantiene una motivación transgresora al querer penetrar en lo que antes ha sido descrito como un espacio casi sagrado: “Quién habitara tu veraz incendio/ rodeado de azucenas por doquiera, / quién entrar a tus dos puertos cerrados / azules y redondos como ojos azules / que aprisionaron todo el sol de día", ${ }^{57}$ esta metáfora, por ejemplo, pone en escena una sexualidad que se opone a la visión tradicional de la Biblia ${ }^{58}$ y que pertenece al plano del erotismo humano en donde por el cuerpo se experimenta la continuidad del ser a través del otro.

En este punto, cabe resaltar que el deseo de continuidad ya había sido expresado desde el principio dentro de la estructura del poema. La última estrofa de la primera parte del poema está formada por versos endecasílabos y alejandrinos que contienen imágenes fragmentarias y es a través de su correspondencia como se van completando, esto bajo

\footnotetext{
${ }^{55}$ Owen, op.cit., p. 103.

${ }^{56}$ Loc.cit.

${ }^{57}$ Loc.cit.

${ }^{58}$ La prohibición del sexo anal en la Biblia está implícita en las leyes sobre las relaciones sexuales expuestas en el libro de Levítico: 18.
} 
una lógica en la cual Ruth sólo puede constituirse a partir de la unión con Booz. Para lograr esto en el poema se recurre al recurso de la anáfora en los verbos imperativos “deja" y "sal", con lo que reafirma la intención de que la amada abandone su individualidad y se una al "yo lírico". Un ejemplo son los versos: “deja la arcilla informe que habitas y que eres / en tanto que mis dedos no modelen tu estatua" ${ }^{, 59}$, aquí los elementos son arcilla/modelar/estatua. Lo anterior brinda una imagen de Ruth como lo incompleto e informe (arcilla) y es sólo a través de la acción (modelar) de Booz como puede cobrar una forma (estatua). Esta misma relación se observa en el resto de los versos a través de elementos como voz/oír/sirena o luz sin sexo/erigir/mujer.

Por último, cabe mencionar que la imagen final de Ruth como una mujer santa instaura de nuevo el obstáculo propio del juego de la seducción, cuya búsqueda en sí misma representa una prolongación del deseo, pues como señala Baudrillard "Mientras que la seducción vulgar procede mediante la insistencia, ésta [la seducción pura] procede mediante la ausencia, o más bien inventa algo así como un espacio curvo, donde los signos son desviados de su trayectoria y devueltos a su origen", ${ }^{60}$ es así como la denegación, el rodeo y la decepción encaminan a provocar en la amada un estado de incertidumbre que terminará por seducirla. En tanto, este "espacio curvo" que lleva de vuelta al origen se refleja en la estructura cíclica del poema y las alusiones del regreso al Caos o el "nacer a la muerte" e incluso en la imagen del "caracol atónito" que descubre el fondo salobre de sus ecos. Lo cíclico también está presente en el encuentro entre Ruth y Booz, ya que la mención: "Vámonos fingiendo que es la primera vez que estoy viviéndote" revela que ya antes se había producido la unión entre los amantes y, por tanto, la experiencia erótica es repetitiva. Es así como se explica que después del encuentro sexual se instaure de nuevo

\footnotetext{
${ }^{59}$ Owen, op.cit., p. 101.

${ }^{60}$ Baudrillard, op. cit., p. 103.
} 
la imposibilidad de unión, pues es necesario que el seductor vuelva a la etapa del vacío para retornar al abandono erótico que ha experimentado: "El iniciado tiene que pasar por una fase de muerte, ni siquiera de sufrimiento patético: de nada, de vacío — último momento antes de la iluminación de la pasión y del abandono erótico", ${ }^{61}$ aquí se inserta la imagen de la huida de Booz: "Ya me voy con mi muerte de música a otra parte".

La reflexión aquí es que en Owen el erotismo se erige como una fuente inagotable de placer ya que el "yo lírico" logra retornar a la experiencia erótica a través de la retirada, propia de la seducción. Al mismo tiempo, esta "fase de muerte" se corresponde con la nostalgia por la continuidad del ser, alcanzada sólo a través del erotismo, ya que es en el encuentro erótico en donde el sujeto cobra una mayor conciencia sobre la muerte, en tanto que ha experimentado la aniquilación del ser individual o como lo llamará Bataille, del ser discontinuo.

\section{El encuentro entre Eros y Tánatos en la experiencia erótica}

Los conceptos de discontinuidad y continuidad, mencionados líneas arriba, se emplean a partir de las nociones que George Bataille introduce en su estudio sobre el erotismo. La primera hace referencia a un estado cerrado que representa la individualidad de cada ser, en tanto que la segunda es el anhelo de renunciar a ese abismo que separa al individuo de los otros para lograr ser uno con el todo. Esta búsqueda se realiza a través del ritual erótico pues, según Bataille: "Toda la operación del erotismo tiene como fin alcanzar al ser en lo más íntimo, hasta el punto del desfallecimiento. El paso del estado normal al estado de deseo erótico supone en nosotros una disolución relativa del ser, tal como está constituido en el orden de la discontinuidad". ${ }^{62}$ Siguiendo esta explicación, en el Libro de Ruth la tercera parte que corresponde al éxtasis amoroso correspondería a la continuidad lograda

\footnotetext{
${ }^{61}$ Ibid., p. 106.

${ }^{62}$ Bataille, op. cit., p. 22.
} 
a través de la fusión con el otro, esto explica por qué Booz consigue salir de sí y equipararse a la juventud de la amada. Posterior a este instante de plenitud acontece la nostalgia por la continuidad perdida, en tanto que el amante no logra prolongarse más en el cuerpo de la amada. De igual modo, la experiencia de continuidad alcanzada en el erotismo da paso al conocimiento de la muerte:

En primer lugar, la perturbación erótica inmediata nos da un sentimiento que lo supera todo; es un sentimiento tal que las sombrías perspectivas vinculadas a la situación del ser discontinuo caen en el olvido. Luego, más allá de la embriaguez abierta a la vida juvenil, nos es dado el poder de abordar la muerte cara a cara y de ver en ella por fin la abertura a la continuidad imposible de entender y de conocer, que es el secreto del erotismo y cuyo secreto sólo el erotismo aporta. ${ }^{63}$

En el poema Booz dice respecto a su encuentro con Ruth: "Y es nacer a la muerte que acecha en los festines de un octubre / sin fin y sin castigo", ${ }^{64}$ este nacimiento hacia la muerte puede entenderse como la revelación de la discontinuidad del ser humano y su carácter perecedero. Lo anterior se liga a la frustración que Booz experimenta después de su unión con Ruth, que deriva de no poder comprender a la amada, en tanto que ésta se constituye como un ser aparte. Es así como la unión entre los amantes se erige como el único medio para la superación de la condición perecedera y la nostalgia por la continuidad es una angustia que se refleja, por ejemplo, en la espera impaciente de Booz al inicio del poema. En ocasiones, esta angustia deriva en un deseo de la propia muerte, sobre todo cuando el amante no puede poseer al ser amado, esto es porque "lo que está en juego en esa furia es el sentimiento de una posible continuidad vislumbrada en el ser amado". ${ }^{65}$

Por último, la unión entre Booz y Ruth también se relaciona con la oposición que guardan los conceptos de reproducción y muerte, puesto que la primera es la prolongación de la discontinuidad a través de la producción de más seres que poseen en sí una

\footnotetext{
${ }^{63}$ Ibid., p. 29.

${ }^{64}$ Owen, op.cit., p. 101.

${ }^{65}$ Bataille, op.cit., p. 25.
} 
individualidad y en tanto que todo nacimiento tiene la condición de una muerte a largo plazo. No es de extrañar entonces que en el poema haya una clara preferencia por la esterilidad de la unión entre los amantes y, más que eso, un rechazo rotundo de Booz hacia el papel de padre que le atribuye el mito cristiano: "Y sólo sé que no soy yo, / el durmiente que sueña un cedro Huguiano, lo que sueñas,". En este punto, la mención "lo que sueñas" parece aludir directamente a Ruth como la amada que está dispuesta a renunciar al erotismo en pos de la reproducción, y es aquí en donde sería comprensible la imposibilidad del romance, puesto que el amante oweniano, como se ha mencionado, es un seductor que se desenvuelve en el terreno del erotismo y el obstáculo. Tras la experiencia del erotismo, los amantes regresan a lo discontinuo, al abismo que separa los cuerpos, Booz ahora expresa: “-y no saber qué eres ni qué estarás soñando. / Hoy te destrozaría por saberlo", ${ }^{66}$ la conciencia del otro se traduce en el distanciamiento físico: "Me miro con tus ojos y me veo alejarme, / y separar las aguas del Mar Rojo de nuestros cuerpos mal fundidos". Finalmente, la retirada hacia la muerte con que finaliza el poema representa, por un lado, la conciencia y la aceptación de ésta al concebirla como una prolongación más hacia la reanudación del erotismo.

Dicho de otro modo, esta interpretación del poema también se traduce como la representación de una reflexión sobre la misma poesía, siendo el "yo lírico" la figura del seductor que, a través de la erotización del lenguaje logra atrapar al lector y sumergirlo en la experiencia poética, después de todo: "La poesía lleva al mismo punto que todas las formas del erotismo: a la indistinción, a la confusión de objetos distintos. Nos conduce a la eternidad, nos conduce hacia la muerte y, por medio de la muerte, a la continuidad: la poesía es la eternidad" ${ }^{67}$

\footnotetext{
${ }^{66}$ Owen, op.cit., p. 104.

${ }^{67}$ Bataille, op. cit., p. 30.
} 


\section{Poesía y erotismo como continuidad}

En el mismo sentir que Bataille, Octavio Paz señala que la relación entre erotismo y poesía es tal, que puede decirse que la primera es una poética corporal y la segunda una erótica verbal:

El erotismo es sexualidad transfigurada: metáfora. El agente que mueve lo mismo el acto erótico que al poético es la imaginación. Es la potencia que transfigura al sexo en ceremonia y rito, al lenguaje en ritmo y metáfora. La imagen poética es abrazo de realidad opuestas y la rima es cópula de sonidos; la poesía erotiza al lenguaje y al mundo porque ella misma, en su modo de operación es ya erotismo. ${ }^{68}$

La poesía como el erotismo conduce a un estado de continuidad a través del poema pues es allí en donde la palabra es capaz de guardar dos o más sentidos al mismo tiempo, destruyendo el paradigma del lenguaje como significado y dando paso a lo que Octavio Paz llama un balbuceo ininteligible en el que "el poema no aspira ya a decir sino a ser". “La línea recta cesa de ser el arquetipo en del círculo y la espiral. Hay un momento en que el lenguaje deja de deslizarse y, favor por decirlo así, se levanta y se mece sobre vacío; hay otro en el que cesa de fluir y se transforma en un sólido transparente- cubo, esfera, obelisco- plantado en el centro de la página" ${ }^{69}$ Lo circular es una imagen recurrente en los Contemporáneos para hablar sobre la poesía, y el caso de Owen no es la excepción, por ello declara: "Ya me hundo a buscarme en un te amé que quiso ser te amo, / donde se desenrolla un caracol atónito al descubrir el fondo/ salobre de sus ecos"70. Lo anterior es reflejo no sólo de la desilusión amorosa, lo es también de la resignación del poeta ante el Caos al que se ha entregado desde un principio porque el tiempo del poema no está en el presente, sino en el pasado en donde se encuentra con las voces de la tradición, aquellos ecos salobres de antiguos poetas que siguen resonando en la poesía de Owen. No obstante, aunque la experiencia del poema termine, el poeta sabe que la poesía es su "muerte de

\footnotetext{
${ }^{68}$ Octavio, Paz, La llama doble, amor y erotismo, Barcelona, Seix Barral, 1998, p. 10.

${ }^{69}$ Ídem., El arco y la lira, Barcelona, Seix Barral, 1993, p. 11.

${ }^{70}$ Owen, op.cit., p. 105.
} 
música”, aquella que se prolonga en el tiempo y por la cual sobreviven los poetas, por la cual Owen puede decir: "sabrán de mi vida por mi muerte”. De igual modo, en el poema Booz dice: "He leído en tu oreja que la recta no existe. / aunque diga que sí tu nariz euclidiana", mientras ve dormir Ruth. En esta imagen se unen forma y contenido, pues mientras se habla de la recreación de la experiencia del erotismo a través de la contemplación de la amada, a la par se alude a la naturaleza de la poesía antes mencionada en las palabras de Paz, es decir que, si el erotismo trasciende la experiencia sexual puramente mecánica, la poesía trasciende el lenguaje para nombrar lo instantáneo.

Comúnmente se estima que la poesía de Owen es hermética y que busca alejarse de las emociones, incluso Jorge Cuesta, compañero de grupo y amigo del poeta, llegó a atribuirle la llamada Ley de Owen que postulaba: "Cuando el aire es homogéneo y casi rígido y las cosas que envuelve no están entremezcladas, el paisaje no es un estado del alma, sino un sistema de coordenadas", ${ }^{71}$ de la que años más tarde el mismo Owen renegaría al decir que ésta era más bien la Ley de Cuesta:

Es la ley que nos exige ordenar la emoción, reprimirla hasta el grado en que parezca haber sido suprimida, simular que no existe, disimular su presencia inevitable, para que el ejercicio poético parezca un mero juego de sombras dentro de una campana neumática, contemplando con los razonadores ojos de la lógica- no de la lógica discursiva, naturalmente, sino de la poética". ${ }^{72}$

En oposición a la visión de Cuesta, Tomás Segovia señala que la Ley de Owen es una "ley desacordada" en donde el sentido del poema va más allá del significado de las palabras. Para Segovia Owen realiza una suplantación de los significados de las palabras a través de "relevos" de imágenes y metáforas, del mismo modo en que se desplaza de una mitología a otra. Lo anterior da al poema un carácter de desplazamiento, que se relaciona con otro de los grandes temas de su obra, el del viaje. Por su parte, Daniel Sada señala que la poesía de Owen posee una "estética de lo imprevisto" que se relaciona con

\footnotetext{
${ }^{71}$ Ibid, p. 243.

${ }^{72}$ Loc. cit.
} 
la pervivencia de "una larga metáfora sobre el desplazamiento y la sensación del viaje sin retorno; ese trayecto ofrece hallazgos que chispean y que dan pie a una lluvia de imágenes activas que en su desborde acaba por diluirse". ${ }^{73}$ En el Libro de Ruth se distingue, por ejemplo, un desplazamiento de la tarde hacia la noche; desde el principio se señala la tarde como el momento de la espera y la pasión: "Todavía la tarde te espera deshojándome, robándote mi carne trozo a trozo:" y poco a poco se irá desplazando hacia las doce de la noche, anunciada como la hora de la muerte: "Así iré mutilándome hasta las doce de la noche". Sandro Cohen ha señalado que "la angustia ante el poder destructivo de la temporalidad se expresa mediante la imagen de la congelación o el deshielo que junto con la imagen del deshoje botánico aparecen en todos los libros de Owen". ${ }^{74}$ Sin duda esta angustia por el paso del tiempo se encuentra presente en versos como: “roja alegría incauta, sol sin freno/ en la tarde que sólo tú detienes, luz demorada sobre mi deshielo", ${ }^{75}$ que expresan la posibilidad de enfrentar la temporalidad a través de la unión con el ser amado.

El procedimiento de desplazamiento se observa además en la personificación del viento que, como viajero, se desplaza desde los rascacielos, hasta la Victoria de Samotracia, para luego regresar de nuevo al campo de espigas en Belén, al igual que los múltiples encabalgamientos presentes, sobre todo, en la contemplación erótica del cuerpo de Ruth, que además contribuyen a la conformación de una imagen unificada del cuerpo:

La isla está rodeada por un mar tembloroso que algunos llaman piel. Pero es espuma. Es un mar que prolonga su blancura en el cielo como el halo de las tehuanas y los santos. Es un mar que está siempre en trance de primera comunión. ${ }^{76}$

73 Daniel, Sada, "Gilberto Owen. La estética de lo imprevisto", Círculo de poesía, 2015. Disponible en: https:/circulodepoesia.com/2015/10/daniel-sada-sobre-gilberto-owen/.

${ }^{74}$ Sandro Cohen citado por J. Whittingham en op.cit., p. 23.

${ }^{75}$ Owen, op.cit., p. 102.

${ }^{76}$ Owen, op.cit., p. 103. 
En estos versos el desplazamiento ocurre en la gradación de los elementos isla, mar, espuma, blancura, cielo, halo, santos, así como con el relevo de la metáfora piel/mar/espuma. Por otra parte, la enumeración y el polisíndeton de conjunciones copulativas sirve para dar unidad de la imagen y el reforzamiento de la expresión poética, por ejemplo, en los versos: "Pasan sin nadie todos los tranvías. / Su huracán de esperanzas no para en las esquinas de mi cuerpo. / Ni su trueno, ni un piano, ni los grillos", ${ }^{77}$ por cierto, estos elementos comparten el atributo de sonoridad y se oponen al silencio inaugural del poema que acontece antes de la llegada de la noche.

Si el silencio y la espera está presente en la inauguración del poema, es preciso decir que el final se distingue por el dominio del Caos y la ambigüedad. J. Whittingham señala que "otra manera de aludir a la naturaleza aparentemente caótica de la existencia consiste en separar objetos que normalmente permanecen juntos" ${ }^{78}$; tal como acontece con la amada cuando Booz sentencia: "Te cambio por tu sombra y te dejo como sin pies sin ella". A medida que ocurre el desplazamiento hacia la medianoche la antítesis Caos/Dios adquiere más sentido pues, efectivamente, lo caótico se instaura como la fuerza dominante. De hecho, sólo hay una mención sutil a Dios a través la mención "Su mano te envolviera en sudarios de inocencia". De acuerdo con Escalante, el dominio del Caos es tanto el triunfo del hijo pródigo que ha vivido la experiencia del amor, como el triunfo del poeta que se traduce en la composición de un poema pleno:

Con este Libro de Ruth que justifica y hasta santifica la más estremecedora de las experiencias. Aunque la relación amorosa ha terminado, y quizás porque ha terminado, Booz, el sujeto de la voz se ha salido con la suya, triunfando por decirlo así en la inevitable derrota. Por eso proclama con orgullo: "La noche es alta y mía" Con este corolario afirmativo culmina la experiencia poética de Owen, más terrenal en tanto más caótica, más sublime en tanto más llevada por el deseo. ${ }^{79}$

\footnotetext{
${ }^{77}$ Ibid., p. 100.

${ }^{78}$ J. Whittingham, op.cit., p. 24.

${ }^{79}$ Escalante, op.cit.
} 
Finalmente, de este Caos se desprende la relación, antes explicada, entre Eros y muerte, que se resalta a través de algunas paradojas como son: "nacer a la muerte" o "he nacido de muerte natural, desesperado". De igual modo, otras veces se recurre al oxímoron para mantener la ambigüedad, en especial en la última parte, en donde el "yo lírico" se marcha a morir, aparentemente derrotado, pero en realidad se va triunfante porque ha logrado la seducción de la amada. Esto queda claro en los versos: “y los confesionarios desenredan mis arrepentimientos mentirosos. / Ya me voy con mi muerte de música a otra parte", ${ }^{80}$ que además resaltan otro tipo de muerte, que no es la del amante en el erotismo, sino la del poeta ante la poesía.

\footnotetext{
${ }^{80}$ Owen, op.cit., p. 105.
} 


\section{CONCLUSIONES}

Llegando al final necesario, que no definitivo, del Libro de Ruth es oportuno resaltar los aspectos antes revisados a fin de poner en relieve los resultados del análisis que permiten observar la riqueza contenida en este gran poema de la literatura mexicana. En este punto, la figura de Gilberto Owen como el poeta errante y misterioso de los Contemporáneos se muestra ya con mayor claridad. Es posible entender la naturaleza de lo mítico en su poesía, en tanto que el mito da forma incluso a su propia biografía. Asimismo, su autonombramiento como la conciencia teológica de los Contemporáneos se entiende ahora como un profundo entendimiento de la existencia humana, comprendida por su cualidad finita y efímera, a la cual Owen abraza, pese a la angustia, como algo fundamental para su mundo poético.

En un viaje de lo mítico a lo poético, el primer capítulo exploró las oposiciones entre el mito y la modernidad presentes en el poema, que indican la importancia que tiene el mito para la constitución de Owen como poeta de lo universal. La mitología le permite insertarse dentro del espíritu del mundo y le posibilita una comprensión más profunda de su expresión poética al encontrar reflejos de sí mismo en los rostros de personajes míticos. Asimismo, este capítulo examinó el origen y significado del libro bíblico en el cual se basa el poema oweniano, esto fue necesario para dar una perspectiva más amplia sobre los atributos originales de los personajes de Booz y Ruth, cuya historia de amor es la inspiración de Owen. Este romance bíblico es de interés para el poeta rosarino porque encuentra en éste una sustancia trascendental, la cual no se relaciona con lo religioso, sino con la carne. Owen realiza entonces una recreación del mito y, aunque selecciona cuadros concretos como el encuentro de los amantes en los campos de trigo, en general desmitifica toda la historia y cierra con un final caótico que culmina en la muerte de Booz, en 
oposición al desenlace mesiánico y esperanzador que tiene el relato original. No obstante, la fatalidad del amante y el Caos encierra más de lo aparente.

En el segundo capítulo tuvo como finalidad revelar lo oculto, es decir, el porqué de la elección de los héroes bíblicos y su historia amorosa. Owen elige voz principal de su poema a Booz porque en él distingue al amante heroico, que no es aquél arquetípico de la mitología judeocristiana, sino el héroe contemporáneo que enfrenta su propia contradicción humana. A pesar de su edad, Booz se incendia en su pasión cuando conoce a Ruth. Detrás de la aparente cautela que el amante mantiene ante la joven está en realidad un deseo por experimentar de nuevo el amor, por seducir al objeto de deseo. Una seducción que en Owen no es conquista, sino desarme y vulnerabilidad. Los amantes owenianos, la mayoría de las veces, se presentan en desventaja ante la amada, vencidos o seducidos por ésta, pero en el Libro de Ruth es Booz quien vence porque se entrega a una muerte gozosa, la de la experiencia erótica en la cual consigue desprenderse de su individualidad e incluso de la fatal temporalidad del mundo para continuarse a través del cuerpo de Ruth.

El capítulo tres se dedicó entonces a explorar la dimensión erótica del poema, en primera instancia se estudió el papel del amante como seductor y se determinó que el uso de las máscaras de Booz y Ruth no sólo son un medio de representación para el "yo lírico" y el propio Owen, sino parte del juego de seducción emprendido para lograr consumar la experiencia erótica. Posteriormente se exploró el erotismo del poema, primero desde sus aspectos transgresores, determinados por la recreación erótica del relato bíblico, la antítesis Caos/Dios y la sexualidad como ritual erótico que se opone a la sexualidad bíblica. Se ahondó también en el sentido del erotismo de acuerdo con las categorías de continuidad y discontinuidad de Bataille, para resaltar la relación entre Eros y la presencia latente de la muerte. Se explicó que es a través de la experiencia erótica cómo el amante 
consigue continuarse en el cuerpo del otro, ya que el erotismo implica una desintegración de la discontinuidad, es decir, del ser individual. En este punto, erotismo y muerte guardan una estrecha similitud, pues ambos son apertura, desnudez y desintegración del "yo" en pos de la integración del ser con el todo.

Finalmente, del análisis del erotismo se desprenden algunas reflexiones en torno a la poesía de Owen, puesto que el erotismo es, como menciona Paz, sexualidad transfigurada en metáfora y la poesía, a su vez, es una erotización del lenguaje. Asimismo, la unión entre la vida y obra de Owen nos muestra cómo la poesía también es un acto de apertura por parte del poeta ante el lector. Owen no teme decir "yo me quemo más cuando escribo", la dificultad formal de sus versos se equipará a la sustancia humana que pone en cada uno de ellos y es por lo que su poesía seduce al lector que, al terminar de leerlo, seguramente seguirá rememorando aquella "muerte de música" oweniana. Si bien durante su vida Owen nunca tuvo interés en ser un poeta conocido e incluso llegó a jactarse de contar sólo con unos cuantos lectores, su apuesta siempre estuvo en la creación de una poesía trascendente. Su aparente hermetismo y dificultad es un camino que hay que recorrer para acceder a la revelación de sus preocupaciones más profundas y así, detrás de cada imagen o metáfora descifrada se muestra la fragmentación de Owen como poeta y hombre que cumple, para con sus lectores, la promesa de sus versos: Pero me romperé. Me he de romper, granada / en la que ya no caben los candentes espejos biselados, y lo que fui de oculto y leal saldrá a los vientos... 


\section{BIBLIOGRAFÍA}

Bataille, George, El erotismo, Madrid, Tusquets Editorial, 1957.

Baudrillard, Jean, De la seducción, Madrid, Ediciones Cátedra, edición digital, 1981.

Caero, B. A. “¿La mano de una mujer? Aspecto histórico, género literario y teología del libro de Rut”, ATUCSC, núm. 12.1., 2010, pp. 91-103. Disponible en: http://repositoriodigital.ucsc.cl/handle/25022009/121

Chumacero, Alí, “Prólogo” en Gilberto Owen, Obras, edición de Josefina Procopio, México, Fondo de Cultura Económica, 1979.

De Rougemont, El amor y Occidente, Barcelona, Kairos, edición digital, 1993.

Escalante, Evodio, “La experiencia poética de Gilberto Owen”, La Jornada Semanal, núm. 548, 4 de septiembre 2005. Disponible en https://www.jornada.com.mx/2005/09/04/sem-evodio.html

Hernández, Belén, "Feliz quien como Sindbad ha hecho un largo viaje (El viaje intertextual de Gilberto Owen)", en El largo viaje de los mitos: Mitos clásicos y mitos prehispánicos en las literaturas latinoamericanas, Roma, Sapienza Universita Editrice, 2020, p. 129-142. Disponible en: http://www.editricesapienza.it/node/7906

Owen, Gilberto, Obras, México, Fondo de Cultura Económica, 1979.

------------------, Me muero de sin usted, cartas de amor a Clementina Otero, México, Siglo XXI Editores, edición digital, 2004.

Paz, Octavio, El arco y la lira, Barcelona, Seix Barral, edición digital, 1993. , La llama doble, amor y erotismo, Barcelona, Seix Barral, edición digital 1998. 
Quirarte, Vicente, El mito, la máscara y el monólogo: el discurso amoroso de Gilberto Owen, Tesis de maestría, México, UNAM. 1989. Disponible en: http://132.248.9.195/pmig2018/0105004/Index.html

Rosas, Alfredo, “Emily Dickinson y Gilberto Owen: ese par de perversos”, La Colmena, núm. 63, 2009, pp. 28-36. Disponible: https://lacolmena.uaemex.mx/article/view/5879

Sada, Daniel, “Gilberto Owen. La estética de lo imprevisto”, Círculo de poesía, 2015. Disponible en: https://circulodepoesia.com/2015/10/daniel-sada-sobre-gilbertoowen/

Sheridan, Guillermo, Los Contemporáneos ayer, México, FCE, 1985.

Sucre, Guillermo, La máscara, la transparencia. Ensayos sobre poesía hispanoamericana, México, FCE, 2001.

Vázquez, Claudio, Gilberto Owen. Dos encuentros, México, UNAM, 2015

Yáñez, R.E. “El lugar del libro de Rut en el canon”, Ciencias religiosas, 18, 2010, pp. 11-21. Disponible en: http://ediciones.ucsh.cl/index.php/rcr/issue/view/89

Whittingham, J., Georgina, “La función de la ironía y de la crítica contemporánea en Gilberto Owen", Texto crítico, 1990, p. 21-35. Disponible en: http://cdigital.uv.mx/handle/123456789/7204 